\title{
Corruption in the Healthcare Sector During the Covid-19 Pandemic: Causes, Consequences and Responses
}

\author{
Rashid M. Ruzanov ${ }^{1}$, Talgat M. Zharlygassinov ${ }^{2 *}$ \\ ${ }^{1}$ Institute of Economics of the Science Committee of the Ministry of Education \\ and Science of the Republic of Kazakhstan, 29 Kurmangazy str., 050010, Almaty, Kazakhstan, \\ ${ }^{2}$ Al-Farabi Kazakh National University, 71 al-Farabi Ave., 050040, Almaty, Kazakhstan
}

\begin{abstract}
The purpose of this article is to analyze the main causes of corruption in the healthcare sector during the COVID-19 pandemic. The study identified the main problems of national health during the pandemic, such as theft and resale of state-funded medicines, vaccines, and medical supplies (medical equipment), reduced availability and quality of medical services, low wages of medical workers, limited supervision and control (monitoring) in the healthcare sector and etc. As a result of the analysis, it was concluded that there is a need for additional work to identify cases of those types of corruption that are indicated in the article. Also, citizens should be involved in suppressing corruption in the health sector - documenting all cases of corruption that can be detected at the place of service delivery. They will serve as strong evidence to advocate for transparency and accountability mechanisms that guarantee more equitable access to health services. The authors argue that one of the important recommendations for preventing corruption in the health sector is investing in prevention as well as enforcing it: developing health system reforms and new health programs to reduce incentives and opportunities for corruption. The results showed that the method of statistical analysis is quite effective in the field of studying corruption. The study of the statistics of corruption crimes allows us to adequately characterize the level of corruption. The sources are statistical data of the Agency of the Republic of Kazakhstan for Combating Corruption, the Bureau of National Statistics, data from international organizations.
\end{abstract}

Keywords: Corruption, National Security, Healthcare Financing, Counteractive Measures to COVID-19, Pandemic.

For citation: Ruzanov, R.M. \& Zharlygassinov, T.M. (2021). Corruption in the Healthcare Sector During the Covid-19 Pandemic: Causes, Consequences and Responses. Economics: the Strategy and Practice, 16(3), 217-226, https://doi.org/10.51176/1997-9967-2021-3-217-226

* Corresponding author: Talgat M. Zharlygassinov- 3rd year Doctoral student of the Specialty «State and Local Government» of the Higher School of Economics and Business of the Al-Farabi Kazakh National University, 050040, Almaty, Al-Farabi avenue 71, Kazakhstan,+87750694843, e-mail: kaztalgin@gmail.com.

Conflict of interests: the authors declare that there is no conflict of interest

Financial support: This research is funded by the Science Committee of the Ministry of Education and Science of the Republic of Kazakhstan (Grant No. AP08856570, Project Leader - Panzabekova A. Zh.)

The article received: 23.08 .2021

The article approved for publication: 03.09 .2021

Date of publication: 30.09.2021 


\title{
Covid-19 пандемиясы кезеңіндегі денсаулық сақтау саласындағы сыбайлас жемқорлық: себептері, салдары және қарсы іс-қимыл шаралары
}

\author{
Рузанов Р.М. ${ }^{1}$, Жарлыгасинов T.М.* \\ ${ }^{1}$ Қазақ̆стан Республикасы Білім және выльмм министрлігі Ғыльмм комитетінің \\ Экономика институты, Құрмангазы к., 29, 050010, Алматы қ.., Қазақұстан, \\ 2 әл-Фараби атындавы Қазақ ұлттық университеті, қ., әл-Фараби даңұвыльl, 71, \\ 050040, Алматы, Қазақстан
}

Түйін

Аталған мақаланың мақсаты COVID-19 пандемиясы кезіндегі денсаулық сақтау саласындағы сыбайлас жемқорлықтың негізгі себептерін талдау болып табылады. Зерттеу барысында пандемия кезіндегі ұлттық денсаулық сақтаудың негізгі проблемалары анықталды, мысалы, мемлекет қаржыландыратын дәрідәрмектерді, вакциналарды және медициналық мақсаттағы заттарды (медициналық жабдықтар) ұрлау және қайта сату, медициналық қызметтердің қол жетімділігі мен сапасының төмендеуі, медицина қызметкерлерінің жалақысының төмендігі, денсаулық сақтау саласындағы шектеулі қадағалау және бақылау (мониторинг) және т.б. Жүргізілген талдау нәтижесінде аталған мақалада көрсетілген сыбайлас жемқорлық түрлерінің жағдайларын анықтау бойынша қосымша жұмыс жүргізу қажеттілігі туралы қорытынды жасалды. Сондайақ, азаматтар денсаулық сақтау саласындағы сыбайлас жемқорлықты жоюға атсалысуы тиіс - қызмет көрсету орнында анықталуы мүмкін барлық сыбайлас жемқорлық жағдайларын құжаттандырып отырулары қажет. Олар медициналық қызметтерге әділ қол жетімділікті қамтамасыз ететін ашықтық пен есеп беру тетіктерін насихаттау үшін сенімді дәлел бола алады. Авторлар денсаулық сақтау саласындағы сыбайлас жемқорлықтың алдын алу жөніндегі маңызды ұсынымдардың бірі - профилактикаға инвестициялау, сондай-ақ оның сақталуын қамтамасыз ету: сыбайлас жемқорлықтың себептері мен мүмкіндіктерін азайту үшін денсаулық сақтау жүйесінің реформаларын және денсаулық сақтаудың жаңа бағдарламаларын әзірлеу болып табылады деп санайды. Нәтижелер сыбайлас жемқорлықты зерттеу саласында статистикалық талдау әдісі өте тиімді екенін көрсетті. Еліміздегі сыбайлас жемқорлық қылмыстарының статистикасын зерделеу сыбайлас жемқорлық деңгейін барабар сипаттауға мүмкіндік береді. Дереккөздер Қазақстан Республикасы Сыбайлас жемқорлыққа қарсы күрес агенттігінің, Ұлттық статистика бюросының статистикалық деректері, халықаралық ұйымдардың.

Түйін сөздер: сыбайлас жемқорлық, ұлттық қауіпсіздік, денсаулық сақтау саласын қаржыландыру, COVID-19 қарсы іс-қимыл шаралары, пандемия.

Дәйексөз алу үшін: Рузанов Р.М., Жарлыгасинов Т.М. (2021). Covid-19 пандемиясы кезеңіндегі денсаулық сақтау саласындағы сыбайлас жемқорлық: себептері, салдары және қарсы іс-қимыл шаралары. Экономика: стратегия және практика, 16(3), 217-226, https://doi.org/10.51176/1997-9967-2021-3-217-226

* Хат-хабаршы авторы: Жарлыгасинов Талгат Мейрканович - әл-Фараби атындағы Қазақ ұлттық университеті Экономика және бизнес жоғары мектебі «Мемлекеттік және жергілікті басқару» мамандығының 3 курс докторанты, 050040, Алматы қ., Әл-Фараби даңғылы, 71, +87750694843, e-mail: kaztalgin@gmail.com.

Мүдделер қақтығысы: авторлар мүдделер қақтығысының жоқтығын мәлімдейді.

Қаржыландыру. Бұл зерттеуді Қазақстан Республикасы Білім және ғылым министрлігінің Ғылым комитеті қаржыландырады (№грант. АР08856570, жоба жетекшісі-Панзабекова А.Ж.)

Мақала редакцияға түсті: 23.08 .2021

Жариялау туралы шешім қабылданды: 03.09.2021

Жарияланды: 30.09.2021 


\title{
Коррупция в сфере здравоохранения в период пандемии Covid-19: причины, последствия и меры противодействия
}

\author{
Рузанов Р.М. ${ }^{1}$, Жарлыгасинов Т.М. ${ }^{2 *}$ \\ ${ }^{1}$ Институт экономики Комитета науки Министерства образования и науки \\ Республики Казахстан, ул. Курмангазы 29, 050010, г. Алматы, Казахстан, \\ ${ }^{2}$ Казахский национальный университет им.аль-Фараби, пр. аль-Фараби 71, \\ 050040, г. Алматы, Казахстан
}

\begin{abstract}
Аннотация
Целью данной статьи является анализ основных причин коррупции в сфере здравоохранения в период пандемии COVID-19. В ходе исследования были выявлены основные проблемы национального здравоохранения в период пандемии, такие как кража и перепродажа финансируемых государством лекарств, вакцин и предметов медицинского назначения (медицинское оборудование), снижение доступности и качества медицинских услуг, низкая заработная плата медицинских работников, ограниченный надзор и контроль (мониторинг) в сфере здравоохранения и т. д. В результате проведенного анализа сделан вывод, о необходимости проведения дополнительной работы по выявлению случаев тех видов коррупции, которые обозначены в данной статье. Также, граждане должны быть задействованы в пресечении коррупции в области здравоохранения - документировать все случаи коррупции, которые могут быть обнаружены на месте предоставления услуг. Они послужат убедительными доказательствами для пропаганды механизмов прозрачности и подотчетности, которые гарантируют более справедливый доступ к медицинским услугам. Авторы считают, что одной из важных рекомендаций по предотвращению коррупции в сфере здравоохранения является инвестирование в профилактику, а также в обеспечение её соблюдения: разработка реформ системы здравоохранения и новых программ здравоохранения для сокращения мотивов и возможностей для коррупции. Результаты исследования показали, что в области изучения коррупции метод статистического анализа достаточно эффективен. Изучение статистики коррупционных преступлений позволяет адекватно охарактеризовать уровень коррупции в стране. Источниками являются статистические данные Агентства Республики Казахстан по борьбе с коррупцией, Бюро национальной статистики, данные международных организаций.
\end{abstract}

Ключевые слова: коррупция, национальная безопасность, финансирование здравоохранения, меры противодействия COVID-19, пандемия.

Для цитирования: Рузанов Р.М., Жарлыгасинов Т.М (2021).Коррупция в сфере здравоохранения в период пандемии Covid-19: причины, последствия и меры противодействия. Экономика: стратегия и практика, 16(3), 217-226, https://doi.org/10.51176/1997-9967-2021-3-217-226

* Корреспондирующий автор: Жарлыгасинов Талгат Мейрканович - докторант 3-го курса специальности «Государственное и местное управление» Высшей школы экономики и бизнеса Казахского национального университета им. аль-Фараби, 050040, г. Алматы, проспект Аль-Фараби 71, +87750694843, e-mail: kaztalgin@, gmail.com.

Конфликт интересов: авторы заявляют об отсутствии конфликта интересов.

Финансирование. Данное исследование финансируется Комитетом по науке Министерства образования и науки Республики Казахстан (грант №. АР08856570, Руководитель проекта - Панзабекова А.Ж.).

Статья поступила в редакцию: 23.08 .2021

Принято решение о публикации: 03.09 .2021

Опубликовано: 30.09 .2021 


\section{Introduction}

In 2019-2020 the world has witnessed an unprecedented global health crisis - the COVID-19 pandemic. In the face of this crisis, governments were forced to take prompt and systemic measures. The priority for most countries has become mass testing of the population, the provision of personal protective equipment, medicines, ventilators, social assistance and business support and other measures to contain and prevent the consequences of the coronavirus. But in some cases, this happened to the detriment of transparency and accountability - in both developed and backward countries, the governance, medical personnel, and the population bypassed corruption prevention mechanisms for specific purposes. With health systems facing high patient congestion, illegal activities, often bribery, are highly likely.

COVID-19 reminded the world that global health should be a national priority for every country. Nonetheless, corruption continues to decisively undermine national health systems. Corrupt activities deprive millions of people of their right to health around the world. The right to health is associated a few for governments: they must ensure the availability, accessibility, acceptability and good quality of medical goods, services and facilities for all, respect for the culture of individuals, ethnic, religious minorities.

The lack of funds to pay bribes for access to medical services can be tragic for patients with COVID-19. In the case of Kazakhstan, corruption during the pandemic inevitably led to a decrease medical services: in June 2020, a shortage of medicines and personal protective equipment broke out in the country (in pharmacies and clinics) [1], which became serious a problem for citizens who were treated at home. Since that time, speculation and illegal circulation of medications and medical devices has been actively carried out in Kazakhstan, both by pharmacists and by other persons who did not have a license and a safety certificate for storing medicines. For those socially vulnerable citizens with coronavirus who were financially difficult to get medicines at inflated prices and who could not pay a bribe to receive proper care, this became a serious problem for treatment.

Cases of theft and embezzlement of money, medicines and other medical equipment, and consumables by frontline medical personnel are widespread throughout the world. The theft and resale of government-funded drugs, vaccines and medical supplies contribute to stock shortages, limiting oversight and control of national health care and limiting patients' access to quality medical treatment. This could ultimately lead to the further spread of coronavirus infection and negative health consequences and effects.
Embezzlement or its absence depends on how well the level of professional, personal norms and morals is developed, staff motivation, supervision rules, reporting and punishment mechanisms. Such indicators can demonstrate the degree of vulnerability of the healthcare system to corruption.

\section{Literature Review}

The issue of corruption is widely considered in foreign literature. R. Merton, D. Torsello in their works believe that effective anti-corruption is possible only through awareness of the culture and peculiarities of different countries [2, 3]. Yu. Songyeon connects the level of corruption with the practice of spreading the democratic tradition, the level of development of legislation and the possibility of access of the poor to public services [4]. N. Kossov, based on a comparative study of the countries of Eastern Europe and Central Asia, connects the fight against corruption with the active activities of public organizations [5]. Alena Ledeneva, a professor at the University of London, draws attention to the ambivalence of consciousness on the issue of corruption, which leads to the appearance of double standards in politics, power dysfunction and doublethink [6].

L.V. Geveling believes that political science approaches corruption, first of all, as a factor that distorts the political organization of society, undermines democratic procedures. Political corruption gives rise to kleptocracy (the power of thieves) - a form of power organization based on corruption and a socio-political group adequate to it. A characteristic feature of political science studies of corruption, according to the expert, is a descriptive, «anecdotal» approach, that is, the emphasis is on describing the state of corruption in specific historical forms of political structure [7].

According to G.K. Mishin, the sociological approach is closely related to the political approach to the study of corruption. Corruption in its sociological interpretation is a social disease, a syndrome of a sick society, an anomie in its Durkheim and Merton interpretations [8].

In Kazakhstan, most of the works are devoted to the legal aspects of the fight against corruption and they offer specific recommendations for improving the current anti-corruption legislation $[9,10,11]$.

Interdisciplinary research is noteworthy. For example, in the study of the sociologist U. This approach was used by Raisov. The study included comprehensive proposals of an economicorganizational and moral-psychological nature aimed at reducing the level of corruption in society [12].

The authors of the publications of the Academy of Public Administration under the 
President of the Republic of Kazakhstan revealed in detail the causes and patterns of corruption development, analyzed socio-economic, legal, cultural, moral and ethical aspects that can effectively counteract corruption [13].

\section{Methodology}

The methodological foundations of the study are scientific works of foreign and domestic scientists, their main provisions, which have a general methodological character for the study of corruption in the Republic of Kazakhstan.

We used both general methods of cognition of reality, and special ones - logical, systemstructural, concrete-sociological and comparative research methods.

The study was carried out on the basis of expert assessments as part of the analysis of the phenomenon of corruption in the healthcare sector. Thanks to this principle, results and, consequently, conclusions were obtained with a sufficiently high objectivity.

In the course of the study, a documentary method was used to study the main factors of corruption in the system of national health care and medicine. Official documents of state authorities and local self-government bodies, the media made it possible to assess the real threat of corruption that can cause the national security of the Republic of Kazakhstan.

The results of the study showed that in the field of studying corruption, the method of statistical analysis is quite effective. The study of statistics on corruption crimes allows us to adequately characterize the level of corruption in the country. The sources are statistical data from the Agency for the Fight against Corruption of the Republic of Kazakhstan, the Bureau of National Statistics of the Ministry of National Economy of the Republic of Kazakhstan, data from international and public organizations (World Bank, Transparency International, etc.).

\section{Findings and discussion}

During the spread of COVID-19, theft in healthcare has become the most urgent problem. It has become an urgent need for many Governments to weaken the system, mechanisms of supervision and punishment. In addition, as serious motives for theft and embezzlement were extreme exhaustion and fear of medical workers, low and insufficient wages, overtime work.

All over the world, there are many reports in the media about the theft of medicines and medical supplies. For example, in Brazil, 15,000 diagnostic tests for coronavirus and more than 2 million personal protective items, including protective glasses, gloves, hand sanitizer and face masks, were stolen from the cargo terminal of the Guarulhos International Airport in São Paulo [14]. Similar situations with the theft of medicines from hospitals occurred in the USA [15], Japan [16], the Netherlands [17], etc. Similar reports appeared in the media of Kazakhstan - 138 doctors were detained by the police for the illegal sale of medicines, medical masks, and other medical devices [18].

Since the beginning of the pandemic, huge financial funds allocated for the fight against the coronavirus have been stolen. An overestimation of the price for the purchase of 132 ventilators worth more than 2 billion tenge was detected and suppressed. During the quarantine period in the city of Nursultan, the branch of the anti-corruption Agency of Kazakhstan managed to return to the budget 7.3 billion tenge of damage from corruption crimes (speculation in the prices of personal protective equipment) [19]. As a result of the fight against corruption in Kazakhstan, 6 political employees were dismissed in 2020,9 political figures, 39 managers holding administrative civil service positions and 5 top managers of the quasi-public sector were brought to disciplinary responsibility [20].

Other manifestations - are charging patients for unnecessary services, operations, medicines, laboratory tests, etc., i.e., the activities of medical workers who form an illegal «placebo effect». To identify the reasons for such actions, it is necessary to disclose the goals of healthcare providers. They may have financial and economic goals, the possibility of career growth, or they may be subjected to pressure from colleagues, management. So, in Aktobe, instead of the necessary medicines, doctors prescribed unnecessary ones to patients with cancer - various vitamins, essentialia, etc. [21]. In 2019, the focus of attention was on the mass appeals of patients in Shymkent to law enforcement agencies with complaints about inappropriate treatment. In the period from 2017 to 2019, a network of medical organizations was created in the city, which, according to the court, received 125 million tenge and did not carry out a high-quality examination and treatment of patients [22]. Patients who did not have the funds to cover their medical expenses had to go into debt, take out loans, because of which they found themselves in even greater financial difficulties. Subsequently, the managers and doctors involved in the medical fraud received a sentence of 5 to 10 years in prison. Similar forms of corruption are found all over the world, both among private and public organizations that provide medical services. Like the domino effect, they ultimately lead to even greater poverty and inequality, seriously harming those who cannot afford high treatment 
costs. For example, in Bangladesh, senior officials of the Ministry of Health approved testing for COVID-19 in two unlicensed clinics. They ended up providing fake coronavirus results to many patients, including Bangladeshis, who then traveled to Italy. During the investigation of the relevant Italian authorities, 65 positive cases were found out of 1,600 residents of Bangladesh who recently arrived in Italy [23]. A similar situation occurred in Kazakhstan - two laboratories in UstKamenogorsk gave false results of PCR tests (out of 100 positive results for COVID-19, only 19 were reliable) [24]. The affected patients suffered additional monetary losses due to the secondary diagnosis for coronavirus.

The next form of corruption in the healthcare sector is associated with a situation where medical workers provide high-quality treatment to patients with whom they are socially connected. These can be family members, friends, acquaintances, and other people who are united by identification markers based on ethnic, religious, ancestral (among Kazakhs), cultural and other characteristics. Even though money is not involved in these cases, there is an illegal type of assistance, intertwined with the implicit and tacit infringement of patients who are not included in his «circle of favorites». It is very difficult to quantify and control the prevalence of this type of corruption in the healthcare sector, but one thing remains clear - such a manifestation creates potential winners and losers, the difference of which can be determined in the degree of provision of medical services. Psychological traits such as a tendency to give preference to family and friends, as well as cultural norms of reciprocity, can influence decision-making by medical professionals.

During the coronavirus pandemic, healthcare workers may experience social pressure from «their group» to give preference to them, ignoring legal norms and principles. For example, nurses may give priority to caring for their family or friends, rather than those who are more in need of help, since «putting family first» can be an important norm in their mental context. Such social norms should be taken into account in a special way, but if they are still used to justify the behavior of a healthcare worker, it will make it difficult to develop effective measures to ensure equitable access to health services. There are few news articles in the media about this phenomenon during the COVID-19 epidemic, however, this does not negate the actual prevalence of this form of corruption in the healthcare system.

Insufficient attitude to the system of remuneration of medical workers in healthcare has also led to corruption in this area. Doctors should receive high pay for their work and at the same time value their reputation and workplace. During the pandemic, the consequences of insufficient funding also led to sad events.

It is worth noting that the state has responded to this problem and has set the task of gradually increasing the salaries of doctors, starting from 2020 , and by 2023 it is planned to increase the salary level several times (table 1). In 2021, expenses in the amount of more than 222 billion tenge are planned to increase the salaries of 247 thousand medical workers, in 2022 - 362 billion tenge, in 2023 - 557 billion tenge.

Table 1 - Planned salary increases for medical workers until 2023, tenge [25]

\begin{tabular}{|l|l|l|l|l|l|l|l|l|l|}
\hline Average salary & $\begin{array}{c}2019 \\
\text { year }\end{array}$ & 2020 year & $\begin{array}{c}\text { Growth } \\
\text { by 2019 }\end{array}$ & $\begin{array}{c}2021 \\
\text { year }\end{array}$ & $\begin{array}{c}\text { Growth } \\
\text { by 2020 }\end{array}$ & $\begin{array}{c}2022 \\
\text { year }\end{array}$ & $\begin{array}{c}\text { Growth } \\
\text { by 2021 }\end{array}$ & $\begin{array}{c}2023 \\
\text { year }\end{array}$ & $\begin{array}{c}\text { Growth } \\
\text { by } 2022\end{array}$ \\
\hline Doctor & 189292 & 246080 & $30 \%$ & 319903 & $30 \%$ & 415875 & $30 \%$ & 561431 & $35 \%$ \\
\hline Average staff & 120459 & 144551 & $20 \%$ & 173461 & $20 \%$ & 190807 & $10 \%$ & 209888 & $10 \%$ \\
\hline
\end{tabular}

However, prevention alone will not be effective. Corruption is a complex phenomenon that can flare up at any opportunity. Therefore, the availability of appropriate punishment mechanisms is of key importance. Even though the citizens of the country have witnessed how high-ranking officials of Kazakhstan and other states were brought to court, arrested or removed from office on charges of corruption, there are not common situations when those who were engaged in corruption at the time of providing services were punished. For the response to COVID-19 to be effective, all participants must be held accountable for their actions.
According to the results of a survey conducted by Transparency International Kazakhstan in 2020, citizens were faced with the fact that violations and corruption in state bodies are headed by [26] state hospitals and polyclinics - $156(27.2 \%)$. Only then comes the police $-55(9.6 \%)$, the land relations Department - $50(8.7 \%)$, the Government for citizens - 44 (7.7\%), etc. (table 2).

In general, state programs deserve special attention. For example, in 2020, during the audit of the implementation of 5 state programs, the Accounts Committee found violations in the amount of 224.2 billion tenge, including financial violations -9.9 billion tenge, inefficient planning and use of budget funds -214.3 billion tenge [27]. 


\section{ТРАНСФОРМАЦИЯ ИНСТИТУЦИОНАЛЬНОЙ СРЕДЫ И ГОСУДАРСТВЕННОЕ УПРАВЛЕНИЕ}

As a result, this opacity is a consequence of the following reasons: the expenditure part of the program budget mainly includes current activities, the formation of national projects requires new approaches aimed at increasing the synchronization of budget and state planning processes, the systematic adjustment of budgets in the direction of increasing expenditures (in some cases it reaches up to 3 times a year), the duplication of state support measures provided for in program documents makes it difficult to assess the effect of financial injections, incorrect placement of development priorities, the list of indicators also includes indicators that are outside the zone of the possibility of managing them by the administrator of the state program.

Thus, all this provides an opportunity for maneuvering for program administrators, while avoiding responsibility. For example, if the industry demonstrates an increase in output or employment indicators, then this gives reason to present it as a successful result of the implementation of the state program.

Table 2-Violations and corruption in state bodies in 2020 [26]

\begin{tabular}{|l|c|c|}
\hline Government agencies / institutions & Frequency & $\%$ \\
\hline State hospitals and polyclinics & 156 & 27,2 \\
\hline Police & 55 & 9,6 \\
\hline Department of Land Relations & 50 & 8,7 \\
\hline CSC (Government for citizens) & 44 & 7,7 \\
\hline State kindergartens & 42 & 7,3 \\
\hline Employment Center & 32 & 5,6 \\
\hline State colleges & 28 & 4,9 \\
\hline Public schools & 25 & 4,4 \\
\hline Military enlistment offices & 24 & 4,2 \\
\hline Tax Service & 24 & 4,2 \\
\hline State universities & 22 & 3,8 \\
\hline Department of Urban Planning Control & 12 & 2,1 \\
\hline The office of the akimat of your district & 11 & 1,9 \\
\hline Department of Employment and Social Protection & 11 & 1,9 \\
\hline Court & 11 & 1,9 \\
\hline Customs Service & 11 & 1,9 \\
\hline Prosecutor's Office & 7 & 1,2 \\
\hline Migration Service/Police & 4 & 0,7 \\
\hline Agency for Civil Service Affairs & 3 & 0,5 \\
\hline Civil Status Registration Department (CRO) & 2 & 0,3 \\
\hline Total: & 752 & 100 \\
\hline
\end{tabular}

Effective implementation of state programs requires the introduction and implementation of indicators that can reflect the real contribution to the development of industries on the basis of state injections. Inefficient programs should either be adjusted to a working state, or closed. A high level of transparency, reasonable use of each tool and disclosure of detailed calculations for each item of expenditure will significantly reduce corruption risks and reduce the flow of dissolving «budget» funds [28].

\section{Conclusion}

One of the important recommendations for preventing corruption in the health sector is investing in prevention as well as ensuring compliance: designing health system reforms and new health programs to reduce the incentives and opportunities for corruption from the outset. A start is likely to be more cost-effective than trying to implement individual anti-corruption measures within a structurally flawed system. This is especially important for the distribution of COVID-19 vaccines. Many countries have started planning for distribution, and this is a key moment to include guarantees of transparency and accountability in priority setting and vaccine distribution.

First, it is necessary to conduct high-quality surveillance and monitoring. Monitoring makes it possible to assess how effectively anti-corruption efforts are working, to identify and respond to emerging new manifestations of corruption and, as a result, to improve health outcomes. As part of the 
COVID-19 pandemic, additional work is needed to identify cases of the types of corruption mentioned in this study. This will help to identify the most common corruption risks at the stage of providing services, who is most affected, how cultural, and social factors contribute to the increase in risks, which medical institutions and which regions are most susceptible to corruption, and what is the overall impact of corruption on the response to COVID-19.

Secondly, citizens should also be involved in countering corruption in the healthcare sector documenting all cases of corruption that can be detected at the place of service delivery. They will serve as strong evidence for promoting transparency and accountability mechanisms that guarantee more equitable access to health services.

Third, it is also important to involve civil society representatives so that they can act as observers and fulfill different roles. Civil society can assess the quality and efficiency of procurement and distribution of medicines and health supplies. For example, they can interact with suppliers and directly support distribution processes; in this case, civil society can be the focal point for the delivery of medical equipment and supplies to hospitals, while keeping records of quantities received and delivered. Above all, they can ensure that governments and institutions, both national and local, remain accountable to their people.

Fourth, domestic and foreign historical experience shows that the complete eradication of corruption is still impossible. Therefore, reasonable supporters of law and order should, without being carried away by illusions and preelection ambitions, be content with only reducing the influence of corruption processes in the life of society. They should set themselves real tasks aimed at reducing the volume of corruption, limiting (localizing) the sphere of its conditioning and spread; change to a less dangerous nature of corruption manifestations; limiting the dangerous mutual influence of domestic and international corruption.

Thus, the COVID-19 epidemic has even more clearly demonstrated the high level of existence of bribery, waste, embezzlement, infringement, and other forms of corruption in the health sector, in both rich and poor societies. The corruption risks associated with the spread of COVID-19 are not just a governance issue. They pose a direct threat to global public health. Any corruption scandal will inevitably shake public confidence in the health care system, which could lead to the world's inability to cope with the crisis.

\section{References}

1. Lekarstv net, no vy derzhites' - bol'nye koronavirusom begajut po aptekam Nur-Sultana $\mathrm{v}$ poiskah preparatov. URL: https://liter.kz/58353-2/ (data accessed: 24.06.2020).

2. Merton, R.K. (1968). Social Theory and Social Structure. New York: The Free Press.

3. Torsello, D. (2011). The ethnographic study of corruption: research themes in political Anthropology. Quality of Government Institute Working Papers.

4. Yu., Songyeon. (2015). Democracy, Inequality and Corruption. Cambridge University Press.

5. Kossow, N. (2014). The Role of Civil Society in the Fight against Corruption: the Story of Ukraine, Asian NGO. URL: http:// issuu.com/asianngo/docs/issue 10 novemberdecember2014. (data accessed: 12.04.2020).

6. Ledeneva, A. (2014). The Ambivalent Future of Ukraine. URL: https://culanth.org/ fieldsights/the-ambivalent-future-of-ukraine (data accessed: 11.05.2020).

7. Geveling, L.V. (2001). Kleptokratija. Social'no-politicheskoe izmerenie korrupcii $i$ negativnoj jekonomiki. Bor'ba afrikanskogo gosudarstva s destruktivnymi formami organizacii vlasti. Moskva.

8. Mishin, G.K. (2001). Korrupcija: ponjatie, sushhnost', mery ogranichenija. Moskva.

9. Smagulov, A.A. Antikorruptsionnaya politika Respubliki Kazakhstan. Teryaya $i$ istoriya gosudarstva $i$ prava, (2), 15-18.

10. Rakhmetov, S.A. (2017). O khode implementatsii norm mezhdunarodnykh konventsii po voprosam bor'by s korruptsiyey $\mathrm{v}$ ugolovnoye zakonodatel'stvo Respubliki Kazakhstan. Vestnik Instituta zakonodatel'stva RK, 2(47), 103-109.

11. Seytkhozhin, B.U. (2014). Kvalifikatsiya korruptsionnykh prestupleniy: teoriya i praktika primeneniya. Karaganda. Izd-vo KEUK.

12. Raisov, U. Ye. (2010). Korruptsiya i yeye sotsial'nyye posledstviya: avtoref. dis.d-ra sotsiol. nauk U. Ye. Raisov, Almaty, 45.

13. Osnovy antikorruptsionnoy kul'tury: uchebnoye posobiye, pod obshchey redaktsiyey d.b.n., professora B. S. Abdrasilova (2016), Astana: Akademiya gosudarstvennogo upravleniya pri Prezidente Respubliki Kazakhstan, 176.

14. Navarrete, M.A. Theft of critical medical equipment surges in Latin America. Insight Crime URL: https://insightcrime.org/news/brief/theftmedical-supplies-latin-america/ (data accessed: 22.04. 2020).

15. Rohrlich, J. An Indiana hospital theft 
shows face masks and hand sanitizer are now sought as sought-after as drugs. Quartz. URL: https://qz.com/1846475/hospital-cleaner-accusedof-stealing-covid-19-masks-and-sanitizer/ (data accessed: 27.04.2020).

16. Covid-19: Thieves steal 6,000 masks from hospital in Japan. CNA. URL: https:// www.channelnewsasia.com/news/asia/robberthieves-steal-6000-hygiene-masks-japancoronavirus-12446862 (data accessed: 18.02.2020).

17. O'Leary, N. Coronavirus: Criminals exploit medical supplies shortage with theft and fraud. Irish Times. URL: https://www.irishtimes. com/news/world/europe/coronavirus-criminalsexploit-medical-supplies-shortage-with-theft-andfraud-1.4212946 (data accessed: 26.03.2020).

18. 138 medikov zaderzhala policija za prodazhu lekarstv. Tengrinews. URL: https:// tengrinews.kz/kazakhstan_news/138-medikovzaderjala-politsiya-za-prodaju-lekarstv-408801/ (data accessed: 20.07.2020).

19. V Nur-Sultane za vremya karantina vernuli $\mathrm{v}$ byudzhet 17 millionov dollarov ot korruptsionnykh prestupleniy. URL: https://www. occrp.org/ru/daily/12270-17-3 (data accessed: 05.05.2020).

20. Shpekbayev o korruptsii vo vremya pandemii: Obogashcheniye na gore svoyego naroda ravnosil'no predatel'stvu i ubiystvu. URL:https:// informburo.kz/novosti/shpekbaev-o-korrupcii-vovremya-pandemii-obogashenie-na-gore-svoegonaroda-ravnosilno-predatelstvu-i-ubijstvu (data accessed: 05.04.2021).

21. Ajbolity s bol'shoj dorogi: neizlechimym bol'nym vrachi naznachajut bespoleznye lekarstva. Karavan. URL: https://www.caravan.kz/ gazeta/ajjbolity-s-bolshojj-dorogi-neizlechimymbolnym-vrachi-naznachayut-bespoleznyelekarstva-529519/ (data accessed: 01.04.2019).
22. V Shymkente vrachej posadili za moshennichestvo: kazahstancy zaplatili im $\$ 300$ 000. Sputnik. URL: https://ru.sputnik. $\mathrm{kz} /$ health/20200916/14978452/V-Shymkentevrachey-posadili-za-moshennichestvokazakhstantsy-zaplatili-im-300-000.html (data accessed: 16.09.2020).

23. Italija priostanovit rejsy iz Bangladesh. Ria. URL: https://ria.ru/20200707/1574004853. html (data accessed: 07.07.2020).

24. Lozhnye diagnozy po koronavirusu vydavali laboratorii v VKO. Nurkz. URL:https:// www.nur.kz/society/1881577-loznye-diagnozypo-koronavirusu-vydavali-laboratorii-v-vko/ (data accessed: 26.10.2020).

25 . Bor'ba s koronavirusnoy infektsiyey, osnashcheniye meditsinskikh organizatsiy, zarplatnaya reforma $\mathrm{v}$ medsfere - razvitiye zdravookhraneniya Kazakhstana v 2020 godu. URL: $\quad$ https://primeminister.kz/ru/news/borbas-koronavirusnoy-infekciey-osnashcheniemedicinskih-organizaciy-zarplatnaya-reformav-medsfere-razvitie-zdravoohraneniyakazahstana-v-2020-godu-121545 (data accessed: 01.06.2021).

26. Transparency Kazakhstan. Monitoring corruption in Kazakhstan for 2020 pod red. Shiyan O.V., Kazakhstan, Almaty (2021), 65.

27. Kratkoye zaklyucheniye k otchetu pravitel'stva respubliki Kazakhstan ob ispolnenii respublikanskogo byudzheta za 2020 god. URL: https://www.gov.kz/memleket/entities/esep/ documents/details/167917?lang=ru (data accessed: 02.06.2021).

28. Pochemu gosprogrammy v Kazakhstane ne rabotayut, i kak izmenit' situatsiyu? URL: https:// camonitor.kz/35066-pochemu-gosprogrammy-Vkazahstane-ne-rabotayut-i-kak-izmenit-situaciyu. html (data accessed: 11.04.2021). 
Information about the authors

Rashid M. Ruzanov - Candidate of Economics, Institute of Economics of the Committee of Science of the Ministry of Education and Science of the Republic of Kazakhstan, Deputy Director for General Issues, e-mail: rashid ruzanov@, mail.ru. ORCID ID: https://orcid.org/0000-0003-4913-3886

*Talgat M. Zharlygassinov-3rd year Doctoral student of the Specialty «State and Local Government» of the Higher School of Economics and Business of the Al-Farabi Kazakh National University, Kazakhstan, e-mail: talgin@gmail. com. ORCID ID: https://orcid.org/0000-0002-1478-6505

\section{Авторлар туралы мәліметтер}

Рузанов Рашид Муратбекович - экономика ғылымдарының кандидаты, Қазақстан Республикасы Білім және ғылым министрлігі Ғылым комитеті Экономика институты, директордың жалпы мәселелер жөніндегі орынбасары, 018018, rashid_ruzanov@,mail.ru. ORCID ID: https://orcid.org/0000-0003-4913-3886

*Жарлыгасинов Талгат Мейрканович - Әл-Фараби атындағы Қазақ ұлттық университеті Экономика және бизнес жоғары мектебі «Мемлекеттік және жергілікті басқару», Қазақстан, мамандығының 3 курс докторанты, e-mail: kaztalgin@gmail.com. ORCID ID: https://orcid.org/0000-0002-1478-6505

\section{Сведения об авторах}

Рузанов Рашид Муратбекович - кандидат экономических наук, Институт экономики Комитета науки Министерства образования и науки Республики Казахстан, заместитель директора по общим вопросам, е-таil: rashid_ruzanov@mail.ru. ORCID ID: https://orcid.org/0000-0003-4913-3886

*Жарлыгасинов Талгат Мейрканович - докторант 3-го курса специальности «Государственное и местное управление» Высшей школы экономики и бизнеса Казахского национального университета им. аль-Фараби, Казахстан, e-mail: kaztalgin@gmail.com. ORCID ID: https://orcid.org/0000-0002-1478-6505 